\title{
Properties of Non-Structural Concrete Made with Mixed Recycled Aggregates and Low Cement Content
}

\author{
Antonio López-Uceda ${ }^{1}$, Jesús Ayuso ${ }^{1, *}$, Martin López ${ }^{1}$, José Ramón Jimenez ${ }^{1}$, \\ Francisco Agrela ${ }^{1}$ and María José Sierra ${ }^{2}$ \\ 1 Construction Engineering, University of Córdoba, Ed. Leonardo Da Vinci, Campus of Rabanales, \\ Córdoba 14071, Spain; p62louca@uco.es (A.L.-U.); ir1loagm@uco.es (M.L.); ir1jiroj@uco.es (J.R.J.); \\ fagrela@uco.es (F.A.) \\ 2 Public Works Agency and Regional Ministry of Public Works and Housing of the Regional Government of \\ Andalusia, Sevilla 41013, Spain; mjsierra@aopandalucia.es \\ * Correspondence: ir1ayuje@uco.es; Tel.: +34-957-218-452; Fax: +34-957-218-550
}

Academic Editor: Jorge de Brito

Received: 21 September 2015; Accepted: 15 January 2016; Published: 26 January 2016

\begin{abstract}
In spite of not being legally accepted in most countries, mixed recycled aggregates (MRA) could be a suitable raw material for concrete manufacturing. The aims of this research were as follows: (i) to analyze the effect of the replacement ratio of natural coarse aggregates with MRA, the amount of ceramic particles in MRA, and the amount of cement, on the mechanical and physical properties of a non-structural concrete made with a low cement content; and (ii) to verify if it is possible to achieve a low-strength concrete that replaces a greater amount of natural aggregate with MRA and that has a low cement content. Two series of concrete mixes were manufactured using 180 and $200 \mathrm{~kg} / \mathrm{m}^{3}$ of CEM II/A-V $42.5 \mathrm{R}$ type Portland cement. Each series included seven concrete mixes: one with natural aggregates; two MRA with different ceramic particle contents; and one for each coarse aggregate replacement ratio $(20 \%, 40 \%$, and $100 \%)$. To study their properties, compressive and splitting tensile strength, modulus of elasticity, density, porosity, water penetration, and sorptivity, tests were performed. The results confirmed that the main factors affecting the properties analyzed in this research are the amount of cement and the replacement ratio; the two MRAs used in this work presented a similar influence on the properties. A non-structural, low-strength concrete (15 MPa) with an MRA replacement ratio of up to $100 \%$ for $200 \mathrm{~kg} / \mathrm{m}^{3}$ of cement was obtained. This type of concrete could be applied in the construction of ditches, sidewalks, and other similar civil works.
\end{abstract}

Keywords: mixed recycled aggregate; ceramics; low cement content; non-structural concrete; mechanical properties; physical properties

\section{Introduction}

Most of the $\mathrm{CO}_{2}$-equivalent produced to manufacture concrete comes from cement production; over $400 \mathrm{~kg}$ of $\mathrm{CO}_{2}$-equivalent is generated per $\mathrm{m}^{3}$ of concrete [1,2], and is also responsible for $5 \%$ of all anthropogenic $\mathrm{CO}_{2}$ emissions [3]. In the European Union, 900 million tonnes of cement were produced in 2008 [4]. In the same year, $\mathrm{CO}_{2}$ equivalent emissions reached 101 million tonnes in the cement production sector [5]. This results in a high contribution to the emission of greenhouse gases, and contributes greatly to global warming.

Construction and demolition waste (CDW) represents almost a third of the total waste generated in the EU [5]. If CDW is not properly managed and is instead deposited in landfills, it can cause serious environmental problems, such as the release of contaminants that pollute surface and ground water [6,7]. Moreover, the recycling and reuse of $\mathrm{CDW}$ in new building materials require less energy consumption, reduce $\mathrm{CO}_{2}$ equivalent emissions, and, as a result, benefit the environment. 
Knoeri et al. [8] significantly reduced the environmental impact of recycled lean concrete by using $100 \%$ mixed rubble aggregates instead of conventional lean concrete. To promote the recycling and reuse of CDW, the Waste Framework Directive 2008/98/EC has mandated a 70\% minimum CDW reuse and recycling rate by 2020. In Spain, the Second National Plan for CDW 2008-2015 [9] was developed to promote the recycling of this waste. This plan set a goal of achieving a recycling rate of $35 \%$ in 2015 .

CDW consists of ceramic particles, mortar, concrete, and natural aggregates, as well as minor amounts of asphaltic material, gypsum, and impurities such as wood, metal particles, paper, and plastics. There are two major classifications of CDW aggregates, depending on their origin: recycled concrete aggregate (RCA), produced by crushing concrete, and mixed recycled aggregate (MRA), including at least $5 \%$ ceramic particles by weight. In Spain, RCA represents approximately $15 \%-20 \%$ and MRA approximately $80 \%$ of the total CDW aggregates produced [10].

In Spain, Structural Concrete Code EHE-08 [11] is the regulatory framework that sets the requirements for all materials used in concrete manufacturing, including recycled aggregates (RA). Among them, the fine fraction of RA is not allowed to be used in concrete manufacturing. The code only permits the use of the coarse fraction of RCA, which limits the replacement ratio of structural concrete to $20 \%$. For non-structural concrete, coarse natural aggregates can be replaced by RCA up to $100 \%$. Both cases exclude concretes manufactured using MRA. The standards in other countries, such as Germany, the United Kingdom, and Portugal, permit the partial or total use of MRA as the coarse fraction in non-structural concrete manufacturing, with different requirements in each country [12]. EHE-08 limits the minimum characteristic strength of non-structural concrete to $15 \mathrm{MPa}$ and minimum cement content to $150 \mathrm{~kg} / \mathrm{m}^{3}$. Because non-structural concretes are not steel reinforced, the EHE-08 code does not include any reference to the environment.

\section{Literary Review}

The possibility of using the coarse fraction of RCA for the partial or total replacement of the coarse fraction of natural aggregates (NA) in the manufacture of structural concrete has been studied by many researchers. It has been observed $[13,14]$ that replacement ratios up to approximately $20 \%$ of RCA have marginal effects on the development of strength in concrete. Exteberría et al. [15] found that the strength of concrete made entirely with RCA was 20\%-25\% lower than conventional concrete after 28 days. Thomas et al. [13] found that a $20 \%$ replacement ratio led to minimal differences in water penetration under pressure and density values, approximately $5 \%$ lower than those of the control concrete. Malešev et al. [16] found a $44 \%$ increase in water absorption by sorptivity with total replacement using RCA with respect to the control concrete.

The effect of recycled aggregates made of pure ceramics has been explored by several authors, who used crushed bricks to replace the coarse fraction of NA. Their results are somewhat diverse. Brito et al. [17] measured strength losses of $45 \%$ with a replacement ratio of $100 \%$, while Cachim [18] found up to $20 \%$ strength losses with $30 \%$ replacement. Similar results were found by Yang et al. [19], who observed a $10 \%$ reduction in strength with $20 \%$ replacement compared to the control concrete. Guerra et al. [20] obtained similar values when replacing up to $9 \%$ of the NA with recycled ceramic materials from sanitary porcelain debris.

However, a few studies have also been dedicated to the possibility of using MRA as a total or partial replacement material for the coarse fraction in the manufacture of concrete [21-27]. The objective of these studies was to obtain a structural concrete with a compressive strength greater than $25 \mathrm{MPa}$. The amount of cement used ranged from $240 \mathrm{~kg} / \mathrm{m}^{3}$ to more than $300 \mathrm{~kg} / \mathrm{m}^{3}$, so the amount of cement under $240 \mathrm{~kg} / \mathrm{m}^{3}$ remains unexplored in studies with MRA incorporation in concrete. It was found that concrete made with MRA has a higher porosity, water absorption, and permeability and a lower strength than the control concretes that were made with NA and the same concrete mix composition. 
The objectives of this work were as follows: (i) to analyze the mechanical and physical properties of a non-structural concrete made with MRA and a low cement content, and to study the effect of three factors: the replacement ratio of natural coarse aggregate by coarse MRA at four levels $(0 \%, 20 \%$, $40 \%$, and $100 \%$ ), the amount of ceramic particles in the MRA at two levels ( $14 \%$ and $30 \%)$ and the amount of cement at two levels ( 180 and $200 \mathrm{~kg} / \mathrm{m}^{3}$ of concrete); and (ii) to verify if it is possible to achieve a low strength concrete that replaces a greater amount of natural aggregate with MRA that has a low cement content. This non-structural concrete could be applied to build ditches, floors, sidewalks, and paving blocks, for which a high mechanical strength is not necessary. The results of this research might have the double environmental benefit of reducing $\mathrm{CO}_{2}$ emissions by reducing the amount of cement and by recycling an RA of low quality, which represents the highest percentage of the CDW aggregates produced.

\section{Materials and Experimental Details}

\subsection{Materials}

\subsubsection{Mixed Recycled Aggregates}

Two mixed recycled aggregates (MRA1 and MRA2) with different percentages of ceramic particles collected on different days from a CDW treatment plant located in Córdoba (South of Spain) were used. These aggregates were by-products of the demolition of residential buildings. The grain size distribution of the materials is shown in Figure 1. Both materials were obtained by sieving the $0-25 \mathrm{~mm}$ fraction produced in the treatment plant.

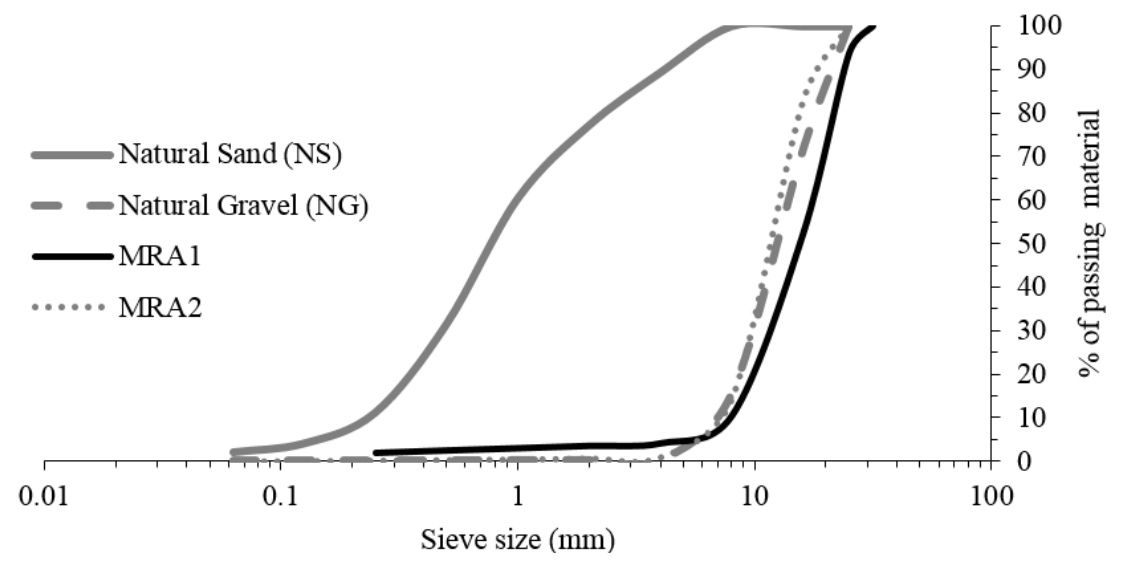

Figure 1. Particle size distribution of aggregates. Mixed recycled aggregates (MRA1 and MRA2).

Table 1 shows the physical and chemical properties as well as the main constituents of the recycled coarse aggregate with the RA constraints of the Spanish Code EHE-08. Only the water absorption requirement was not satisfied by MRA2, although, for RILEM (The International Union of Laboratories and Experts in Construction Materials, Systems and Structures) [28], the limit is less restrictive and up to $20 \%$ is allowed. It was noted that the amount of ceramic particles in MRA2 was greater than that in MRA1, so that, the absorption was higher in MRA2. MRA2 complies with the EHE-08 requirements, whereas MRA1 does not, as its total sulfur content slightly exceeds the EHE-08 limit. In the literature review, different classifications have been proposed based on properties or compositions of the two MRA. Agrela et al. [29] established a classification for RA that depends on the ceramic and concrete particle content. In this scheme, MRA1 was classified as mixed recycled aggregate (MixRA), because its ceramic content was between $10 \%-30 \%$ by weight. MRA2 was classified as a ceramic recycled aggregate (CerRA) because its ceramic content was over 30\% by weight. Silva et al. [30] suggested a different RA classification based on the oven-dried density, water absorption, and Los Angeles 
(LA) abrasion value. In the latter scheme, MRA1 was classified as B-II because its oven-dried density was higher than $2.2 \mathrm{Mg} \cdot \mathrm{m}^{-3}$, and its water absorption and LA values were lower than $6.5 \%$ and 45, respectively. Conversely, MRA2 was classified as C-I because its oven-dried density was over $2.0 \mathrm{Mg} \cdot \mathrm{m}^{-3}$, and its water absorption and LA values were lower than $10.5 \%$ and 50 , respectively.

Table 1. Physical, chemical properties and components of mixed recycled aggregates (MRA). SSD: Saturated surface dry.

\begin{tabular}{|c|c|c|c|c|}
\hline Physical Properties & According to Standard & MRA1 & MRA2 & EHE-08 Requirements \\
\hline Water absorption (\%) & UNE-EN 1097-6:2014 [31] & 6.1 & 9.0 & $<5 \%$ General, $<7 \%$ RCA \\
\hline Oven-dried density $\left(\mathrm{Mg} / \mathrm{m}^{3}\right)$ & UNE-EN 1097-6:2014 [31] & 2.24 & 2.08 & - \\
\hline SSD density $\left(\mathrm{Mg} / \mathrm{m}^{3}\right)$ & UNE-EN 1097-6:2014 [31] & 2.38 & 2.27 & - \\
\hline Flakiness index $(\%)$ & UNE-EN 933-3:2012 [32] & 10.8 & 14.7 & $<35$ \\
\hline Los Angeles Abrasion test & UNE-EN 1097-2:2010 [33] & 35.6 & 32.3 & $<40$ \\
\hline Freeze-thaw resistance (\%) & UNE-EN 1367-2:2010 [34] & 5.2 & 14.0 & $<18 \%$ \\
\hline Chemical properties & According to Standard & MRA1 & MRA2 & EHE-08 Requirements \\
\hline Total sulfur content (\% S) & UNE-EN 1744-1-11:2010 [35] & 1.02 & 0.96 & $<1$ \\
\hline Acid-soluble sulfates $\left(\% \mathrm{SO}_{3}\right)$ & UNE-EN 1744-1-12:2010 [36] & 0.65 & 0.62 & $<0.8$ \\
\hline Chlorides $(\%)$ & UNE-EN 1744-1-7:2010 [37] & $<0.01$ & $<0.01$ & $<0.05$ \\
\hline Components (\%) & UNE-EN 933-11:2009 [38] & - & - & - \\
\hline Asphalt & - & 0.9 & 0.5 & - \\
\hline Ceramics & - & 13.9 & 30.2 & - \\
\hline Mortar and concrete & - & 49.0 & 44.6 & - \\
\hline Unbound aggregates & - & 34.9 & 24.0 & - \\
\hline Gypsum & - & 0.4 & 0.5 & - \\
\hline Others (wood, glass, plastic, and metal) & - & 0.9 & 0.2 & - \\
\hline
\end{tabular}

\subsubsection{Natural Aggregates}

Figure 1 illustrates the grain size distribution of natural siliceous sand (NS) with a maximum size of $4 \mathrm{~mm}$, and siliceous gravel (NG) with a 6-25 mm fraction. The most important physical and chemical properties of natural aggregates for concrete production are summarized in Table 2.

Table 2. Physical and chemical properties of natural aggregates (NA). NS = Natural siliceous sand, NG = Siliceous gravel.

\begin{tabular}{cccc}
\hline Physical Properties & According to Standard & NS & NG \\
\hline Water absorption (\%) & UNE-EN 1097-6:2014 [31] & 0.92 & 0.73 \\
SSD density $\left(\mathrm{Mg} / \mathrm{m}^{3}\right)$ & UNE-EN 1097-6:2014 [31] & 2.66 & 2.70 \\
Flakiness index (\%) & UNE-EN 933-3:2012 [30] & - & 20.60 \\
Los Angeles abrasion test & UNE-EN 1097-2:2010 [33] & - & 18.10 \\
Friability test & UNE 83115:1989 [39] & 12.40 & - \\
\hline Chemical properties & According to Standard & NS & NG \\
\hline Total sulfur content (\% S) & UNE-EN 1744-1-11:2010 [35] & 0.36 & 0.57 \\
Acid-soluble sulfates (\% SO 3 ) & UNE-EN 1744-1-12:2010 [36] & 0.17 & 0.51 \\
Chlorides (\%) & UNE-EN 1744-1-7:2010 [37] & $<0.01$ & $<0.01$ \\
\hline
\end{tabular}

\subsubsection{Cement}

A CEM II/A-V 42.5 R type Portland cement was used. The cement properties are shown in Table 3. The cement used for this study had a fly ash content of $17 \%$, which was produced from the emissions of a nearby coal-fired power plant. This represents a significant benefit in $\mathrm{CO}_{2}$ emission reduction [40].

Table 3. Chemical composition and physical properties of cement.

\begin{tabular}{|c|c|c|c|c|c|c|c|c|c|}
\hline \multirow{2}{*}{$\begin{array}{c}\text { Loss on } \\
\text { Ignition (\%) }\end{array}$} & \multirow{2}{*}{$\begin{array}{l}\text { Specific Mass } \\
\left(\mathrm{Mg} / \mathrm{m}^{3}\right)\end{array}$} & \multirow{2}{*}{$\begin{array}{c}\text { Blaine Specific } \\
\text { Surface Area }\left(\mathrm{m}^{2} / \mathrm{kg}\right)\end{array}$} & $\mathrm{SiO}_{2}$ & $\mathrm{Al}_{2} \mathrm{O}_{3}$ & $\mathrm{Fe}_{2} \mathrm{O}_{3}$ & $\mathrm{MgO}$ & $\mathrm{CaO}$ & $\mathrm{Na}_{2} \mathrm{O}$ & $\mathrm{K}_{2} \mathrm{O}$ \\
\hline & & & \multicolumn{7}{|c|}{$(\%)$} \\
\hline 1.38 & 2.89 & 351.9 & 26.49 & 8.70 & 3.31 & 1.41 & 54.36 & 3.26 & 1.43 \\
\hline
\end{tabular}




\subsubsection{Admixtures}

Two admixtures were used in this study. The plasticizer Conplast MR260 is formulated as a mixture of synthetic and natural polymers. Its main function is to increase the workability of a material. The superplasticizer Conplast SP420 is based on organic polymers. Its main function is to reduce the water-to-cement ratio.

\subsection{Experimental Details.}

\subsubsection{Mix Proportions}

The mix proportion was a commercial design provided by PREBESUR SL (Córdoba, Spain), an industrial concrete plant located in Córdoba (Spain). The concrete mixes were designed to evaluate the influence of the following factors on the mechanical and durability properties of concrete:

- Amount of cement. Two cement contents were used: 180 and $200 \mathrm{~kg} / \mathrm{m}^{3}$.

- Replacement ratio of coarse aggregate. Four levels were used: $0 \%, 20 \%, 40 \%$, and $100 \%$. The replacement percentage was calculated using the equivalent volume.

- Type of MRA. Two MRA (MRA1 and MRA2) were tested, with different percentages of ceramic particles.

Two series of concrete mixes were produced with a constant water-to-cement ratio of 0.65: one for a cement content of $180 \mathrm{~kg} / \mathrm{m}^{3}$ and the other for a cement content of $200 \mathrm{~kg} / \mathrm{m}^{3}$. Each series consisted of seven concrete mixes: one with natural aggregates that acted as control concrete (CC); one for each type of MRA (CMRA1 and CMRA2); and one for each replacement ratio (20\%, 40\%, and 100\%). Tables 4 and 5 illustrate the concrete mix proportions for each series.

Table 4. Composition of the concrete mixes for Series I (180 kg of cement $\left./ \mathrm{m}^{3}\right)$. CC: Control concrete.

\begin{tabular}{ccccccccc}
\hline \multirow{2}{*}{ Samples } & $\begin{array}{c}\text { Replacement } \\
\text { Ratio (\%) }\end{array}$ & Cement & Water & NS & NG & MRA & Plasticizer & Superplasticizer \\
\cline { 3 - 8 } & 0 & 180 & 117 & 1100 & 950 & 0 & 1.92 & 2.15 \\
CC-I & 20 & 180 & 117 & 1100 & 759 & 147 & 1.92 & 2.15 \\
CMRA1-20-I & 40 & 180 & 117 & 1100 & 569 & 294 & 1.92 & 2.15 \\
CMRA1-40-I & 100 & 180 & 117 & 1100 & 0 & 735 & 1.92 & 2.15 \\
CMRA1-100-I & 20 & 180 & 117 & 1100 & 817 & 144 & 1.92 & 2.15 \\
CMRA2-20-I & 40 & 180 & 117 & 1100 & 613 & 288 & 1.92 & 2.15 \\
CMRA2-40-I & 100 & 180 & 117 & 1100 & 0 & 720 & 1.92 & 2.15 \\
CMRA2-100-I & & & & & & & & \\
\hline
\end{tabular}

Table 5. Composition of the concrete mixes for Series II (200 kg of cement $\left./ \mathrm{m}^{3}\right)$.

\begin{tabular}{ccccccccc}
\hline \multirow{2}{*}{ Samples } & $\begin{array}{c}\text { Replacement } \\
\text { Ratio (\%) }\end{array}$ & Cement & Water & NS & NG & MRA & Plasticizer & Superplasticizer \\
\cline { 3 - 8 } & 0 & 200 & 130 & 1070 & 950 & 0 & 2.13 & 2.39 \\
CC-II & 20 & 200 & 130 & 1070 & 759 & 147 & 2.13 & 2.39 \\
CMRA1-20-II & 40 & 200 & 130 & 1070 & 569 & 294 & 2.13 & 2.39 \\
CMRA1-40-II & 100 & 200 & 130 & 1070 & 0 & 735 & 2.13 & 2.39 \\
CMRA1-100-II & 20 & 200 & 130 & 1070 & 817 & 144 & 2.13 & 2.39 \\
CMRA2-20-II & 40 & 200 & 130 & 1070 & 613 & 288 & 2.13 & 2.39 \\
CMRA2-40-II & 100 & 200 & 130 & 1070 & 0 & 720 & 2.13 & 2.39 \\
CMRA2-100-II & & & & & & & & \\
\hline
\end{tabular}

To increase the workability and reduce the amount of water, two additives were used in all the mixes: plasticizer, with a density of $1.184 \mathrm{~g} / \mathrm{cm}^{3}$ and superplasticizer, with a density of $1.195 \mathrm{~g} / \mathrm{cm}^{3}$, were added at $9 \mathrm{~mL} / \mathrm{kg}$ and $10 \mathrm{~mL} / \mathrm{kg}$ of cement, respectively. The target was to achieve an S3 slump class, according to UNE-EN-206-1:2008 [41].

\subsubsection{Mixing Process}

MRA have a high water absorption capacity that reduces the workability of fresh concrete and water available for cement hydration. Therefore, some authors $[25,42]$ recommend an initial wetting of 
the MRA before the mixing process. As such, the MRA were flooded for 10 minutes prior to mixing. It was estimated that during this wetting period MRA absorb $80 \%$ of their total capacity [24]. Figure 2 presents the scheme of the mixing process.

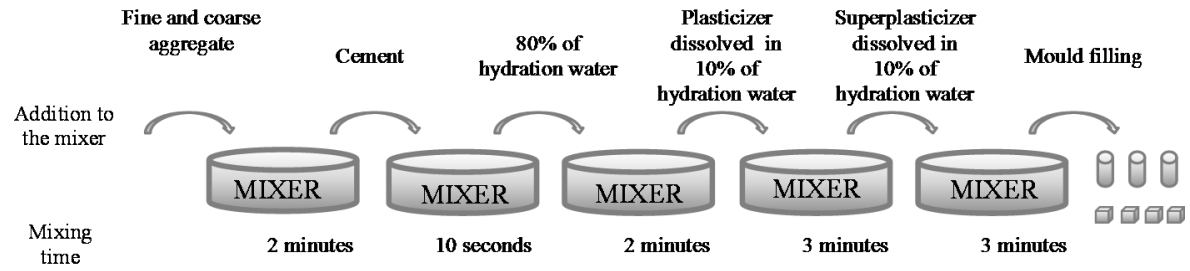

Figure 2. Mixing process diagram.

\subsubsection{Test Method}

The mechanical and physical properties were measured at an age of 28 days. Three samples were tested for each test. All the specimens were demoulded at $24 \mathrm{~h}$ and then cured in a chamber at constant temperature $\left(23^{\circ} \mathrm{C} \pm 2{ }^{\circ} \mathrm{C}\right)$ and relative humidity $(95 \% \pm 5 \%)$. Table 6 summarizes all the tests that were performed.

Table 6. Tests performed to study the properties of concrete.

\begin{tabular}{ccc}
\hline Test & Standards & Form and Sample Dimensions \\
\hline Slump test for workability & UNE-EN 12350-2:2009 [43] & Cubic: $100 \times 100 \times 100 \mathrm{~mm}$ \\
Compressive strength & UNE-EN 12390-3:2009 [44] & Cylindrical: $\varnothing 150 \times 300 \mathrm{~mm}$ \\
Tensile splitting strength & UNE-EN 12390-6:2009 [45] & Cylindrical: $\varnothing 100 \times 200 \mathrm{~mm}$ \\
Static modulus of elasticity in compression & UNE 83316:1996 [46] & Cylindrical: $\varnothing 150 \times 300 \mathrm{~mm}$ \\
Density of hardened concrete & UNE-EN 12390-7:2009 [47] & Cubic: $150 \times 150 \times 150 \mathrm{~mm}$ \\
Porosity of hardened concrete & UNE-EN 12390-7:2009 [47] & Cubic: $150 \times 150 \times 150 \mathrm{~mm}$ \\
Penetration of water under pressure & UNE-EN 12390-8:2009 [48] & Cylindrical: $\varnothing 150 \times 300 \mathrm{~mm}$ \\
Determination of sorptivity & UNE- EN 1925:1999 [49] & Cubic: $100 \times 100 \times 100 \mathrm{~mm}$ \\
\hline
\end{tabular}

\section{Results and Discussion}

The mean values of the results of all tests carried out for each concrete mix with the coefficients of variation are shown in Table 7 . All the coefficients of variation were low, which justifies the use of only three replicates. To assess the significance of the effect of the three categorical factors on each of the properties, an analysis of variance (ANOVA) was conducted with the statistical software Statgraphics Centurion XVI (Version 16.1.18, StatPoint Technologies, Inc., Warrenton, VA, USA). The F-test in the ANOVA analysis was used to evaluate whether one factor had statistically significant effects on the properties studied, with a 95\% confidence level. If the $p$-value was lower than 0.05 , the factor showed a significant effect on the property studied. To check whether there was a significant difference between the groups for each factor, Fisher's Least Significant Difference (LSD) test was conducted to examine the mean plot and identify the LSD intervals that did not overlap.

Table 8 shows a summary of the results obtained with the ANOVA. The results indicate that the percentage of replacement has an influence on all the mechanics and physical properties analyzed and the type of aggregate has no influence on any of the properties, which proves that the two recycled aggregates used in this research were of comparable characteristics. The amount of cement has influence on compressive and splitting tensile strength, as well as on the density and penetration of water under pressure. Additionally, the degrees of freedom n1 and n2 ( $n 1$ is equal to factor levels minus one and $\mathrm{n} 2$ is equal to the number of observations minus factor levels) considered for the F-Snedecor contrast are indicated. 
Table 7. Means values of the results of all tests.

\begin{tabular}{|c|c|c|c|c|c|c|c|c|c|c|c|c|c|c|c|c|}
\hline Samples & $\begin{array}{l}f_{\text {ccub, }} \\
\text { MPaa }\end{array}$ & $c . v$ & $\begin{array}{l}f_{\text {ccyl, }} \\
\text { MPaa }\end{array}$ & $c . v$. & $\begin{array}{c}\text { Splitting } \\
\text { Tensile } \\
\text { Strength, MPa }\end{array}$ & $c . v$. & $\begin{array}{l}\text { Modulus of } \\
\text { Elasticity, } \\
\text { GPa }\end{array}$ & $c . v$ & $\begin{array}{l}\text { SSD-Density, } \\
\mathrm{Mg} \cdot \mathrm{m}^{-3}\end{array}$ & $c . v$. & $\begin{array}{c}\text { Porosity, } \\
\%\end{array}$ & $c . v$. & $\begin{array}{c}\text { Water } \\
\text { Penetration, } \\
\mathrm{mm}\end{array}$ & $c . v$. & $\begin{array}{l}\text { Sorptivity, } \\
\mathbf{m m} \cdot \mathbf{h}^{-1 / 2}\end{array}$ & $c . v$. \\
\hline CC-I & 29.0 & 1.37 & 20.8 & 2.53 & 2.42 & 2.74 & 15.3 & 3.94 & 2.31 & 0.74 & 11.7 & 1.41 & 57.0 & 6.24 & 0.57 & 7.17 \\
\hline CMRA1-20-I & 23.8 & 1.01 & 19.6 & 1.68 & 2.36 & 3.78 & 14.5 & 2.35 & 2.29 & 0.50 & 11.8 & 2.16 & 89.0 & 3.31 & 0.59 & 6.92 \\
\hline CMRA1-40-I & 20.5 & 4.26 & 18.6 & 0.90 & 2.02 & 3.52 & 12.5 & 5.94 & 2.25 & 0.44 & 13.3 & 1.62 & 96.0 & 3.90 & 0.76 & 6.45 \\
\hline CMRA1-100-I & 18.5 & 1.14 & 17.3 & 4.86 & 1.58 & 15.68 & 10.5 & 9.06 & 2.24 & 0.10 & 14.1 & 0.72 & 97.5 & 7.26 & 0.94 & 4.84 \\
\hline CMRA2-20-I & 21.7 & 1.95 & 20.0 & 1.45 & 2.35 & 6.02 & 14.4 & 2.96 & 2.26 & 0.19 & 12.2 & 1.39 & 63.0 & 9.07 & 0.62 & 12.58 \\
\hline CMRA2-40-I & 21.1 & 0.56 & 19.2 & 0.21 & 2.10 & 2.26 & 12.8 & 3.58 & 2.24 & 0.42 & 13.1 & 1.27 & 74.7 & 7.91 & 0.81 & 9.07 \\
\hline CMRA2-100-I & 20.5 & 0.82 & 19.0 & 0.77 & 1.97 & 10.58 & 11. 9 & 1.56 & 2.20 & 0.47 & 13.9 & 0.37 & 76.5 & 3.74 & 0.99 & 7.05 \\
\hline CC-II & 34.6 & 2.74 & 25.8 & 0.54 & 2.81 & 1.28 & 17.6 & 3.87 & 2.38 & 0.51 & 10.9 & 1.35 & 34.0 & 8.66 & 0.25 & 14.93 \\
\hline CMRA1-20-II & 32.7 & 1.20 & 24.8 & 1.43 & 2.60 & 3.02 & 15.8 & 2.84 & 2.36 & 0.23 & 11.3 & 1.10 & 45.3 & 9.24 & 0.36 & 9.46 \\
\hline CMRA1-40-II & 30.1 & 0.42 & 23.6 & 0.97 & 2.29 & 3.97 & 15.5 & 2.86 & 2.33 & 0.31 & 13.2 & 0.88 & 52.7 & 5.44 & 0.55 & 3.93 \\
\hline CMRA1-100-II & 22.8 & 4.26 & 20.5 & 0.90 & 2.18 & 3.52 & 11.6 & 8.60 & 2.25 & 0.54 & 13.9 & $\begin{array}{l}0.00 \\
1.43\end{array}$ & 78.0 & $\begin{array}{l}6.28 \\
6.28\end{array}$ & 0.89 & 6.66 \\
\hline CMRA2-20-II & 34.5 & $\begin{array}{l}4.20 \\
0.63\end{array}$ & 25.0 & 1.77 & 2.63 & $\begin{array}{l}3.192 \\
2.19\end{array}$ & $\begin{array}{l}1.0 \\
16.7\end{array}$ & $\begin{array}{l}2.00 \\
2.29\end{array}$ & 2.30 & $\begin{array}{l}0.64 \\
0.62\end{array}$ & 11.5 & $\begin{array}{l}1.45 \\
1.97\end{array}$ & 36.3 & $\begin{array}{l}7.20 \\
7.16\end{array}$ & 0.56 & $\begin{array}{l}0.000 \\
5.15\end{array}$ \\
\hline CMRA2-40-II & 33.8 & $\begin{array}{l}0.00 \\
3.66\end{array}$ & 24.5 & 1.29 & $\begin{array}{l}2.03 \\
2.35\end{array}$ & 2.83 & $\begin{array}{l}10.7 \\
16.2\end{array}$ & 2.47 & $\begin{array}{l}2.50 \\
2.29\end{array}$ & 0.16 & $\begin{array}{l}1.3 .1 \\
13.1\end{array}$ & 0.94 & $\begin{array}{l}45.3 \\
45.3\end{array}$ & $\begin{array}{l}7.10 \\
7.28\end{array}$ & $\begin{array}{l}0.00 \\
0.73\end{array}$ & $\begin{array}{l}3.10 \\
5.59\end{array}$ \\
\hline CMRA2-100-II & 27.6 & 3.94 & 23.4 & 1.20 & 2.21 & 7.23 & 13.1 & 4.83 & 2.25 & 0.50 & 13.5 & 0.10 & 76.5 & 6.94 & 1.03 & 3.76 \\
\hline
\end{tabular}


Table 8. Summary results of ANOVA and coefficient of variation.

\begin{tabular}{|c|c|c|c|c|c|c|c|c|c|}
\hline \multirow{2}{*}{ Properties } & \multirow[b]{3}{*}{ Factor levels } & \multicolumn{8}{|c|}{ Factors } \\
\hline & & \multicolumn{2}{|c|}{$\begin{array}{c}\text { Amount of } \\
\text { Cement }\left(\mathrm{kg} / \mathrm{m}^{3}\right)\end{array}$} & \multicolumn{4}{|c|}{ (\%) of Replacement } & \multicolumn{2}{|c|}{ Type or MRA } \\
\hline \multirow{2}{*}{-} & & 180 & 200 & 0 & 20 & 40 & 100 & 1 & 2 \\
\hline & $\begin{array}{l}\text { Degrees of } \\
\text { freedom }\end{array}$ & \multicolumn{2}{|c|}{$(1 ; 12)$} & \multicolumn{4}{|c|}{$(3 ; 10)$} & \multicolumn{2}{|c|}{$(1 ; 10)$} \\
\hline \multirow{2}{*}{$\begin{array}{l}\text { Compressive strength } \\
\left(f_{\text {ccyl }}\right)\end{array}$} & $p$-value & \multicolumn{2}{|c|}{$<0.0001$} & \multicolumn{4}{|c|}{$<0.0001$} & \multicolumn{2}{|c|}{0.5477} \\
\hline & c.v. & 5.3 & 6.7 & 7.4 & 3.6 & 2.1 & 9.9 & 8.1 & 2.9 \\
\hline \multirow{2}{*}{$\begin{array}{l}\text { Tensile splitting } \\
\text { strength }\end{array}$} & $p$-value & \multicolumn{2}{|c|}{0.0439} & \multicolumn{4}{|c|}{$<0.0001$} & \multicolumn{2}{|c|}{0.6006} \\
\hline & c.v. & 13.0 & 9.2 & 13 & 8.5 & 4.5 & 16.4 & 12.9 & 7.5 \\
\hline \multirow{2}{*}{$\begin{array}{l}\text { Modulus of elasticity } \\
\text { in compression }\end{array}$} & $p$-value & \multicolumn{2}{|c|}{0.0647} & \multicolumn{4}{|c|}{$<0.0001$} & \multicolumn{2}{|c|}{0.5225} \\
\hline & c.v. & 11.9 & 12.9 & 13.9 & 8.0 & 4.4 & 21.6 & 14.5 & 9.5 \\
\hline \multirow{2}{*}{$\begin{array}{c}\text { Density of } \\
\text { hardened concrete }\end{array}$} & $p$-value & \multicolumn{2}{|c|}{0.0443} & \multicolumn{4}{|c|}{$<0.0001$} & \multicolumn{2}{|c|}{0.2568} \\
\hline & c.v. & 1.5 & 2.0 & 2.7 & 1.4 & 0.7 & 2.3 & 1.6 & 1.5 \\
\hline \multirow{2}{*}{$\begin{array}{c}\text { Porosity of } \\
\text { hardened concrete }\end{array}$} & $p$-value & \multicolumn{2}{|c|}{0.5132} & \multicolumn{4}{|c|}{$<0.0001$} & \multicolumn{2}{|c|}{0.9602} \\
\hline & c.v. & 7.1 & 9.0 & 12.3 & 8.5 & 4.0 & 8.5 & 8.2 & 6.3 \\
\hline \multirow{2}{*}{$\begin{array}{l}\text { Penetration of water } \\
\text { under pressure }\end{array}$} & $p$-value & \multicolumn{2}{|c|}{0.0023} & \multicolumn{4}{|c|}{0.0016} & \multicolumn{2}{|c|}{0.1081} \\
\hline & c.v. & 18.5 & 31.6 & 44.9 & 22.3 & 14.1 & 24.1 & 20.1 & 22.6 \\
\hline \multirow{2}{*}{ Sorptivity } & $p$-value & & & & & & & & \\
\hline & c.v. & 20.8 & 41.3 & 72.0 & 32.4 & 9.9 & 29.6 & 27.3 & 26.2 \\
\hline
\end{tabular}

\subsection{Effect of Cement Content}

\subsubsection{Mechanical Properties}

As seen in Figure 3 , the mean values for all of the mixes of cylindrical specimens ( $f_{\text {ccyl }}$ values) with 200 and $180 \mathrm{~kg}$ of cement $/ \mathrm{m}^{3}$ were 24.0 and $19.2 \mathrm{MPa}$, respectively, with a decrease of $19.8 \%$. There were statistically significant differences at a $95 \%$ confidence level, as is indicated by the non-overlapping bars in Figure 3. Mas et al. [23] obtained a greater compressive strength decrease of $46.4 \%$ between 360 and $240 \mathrm{~kg}$ of cement $/ \mathrm{m}^{3}$ series, due to a higher cement content.
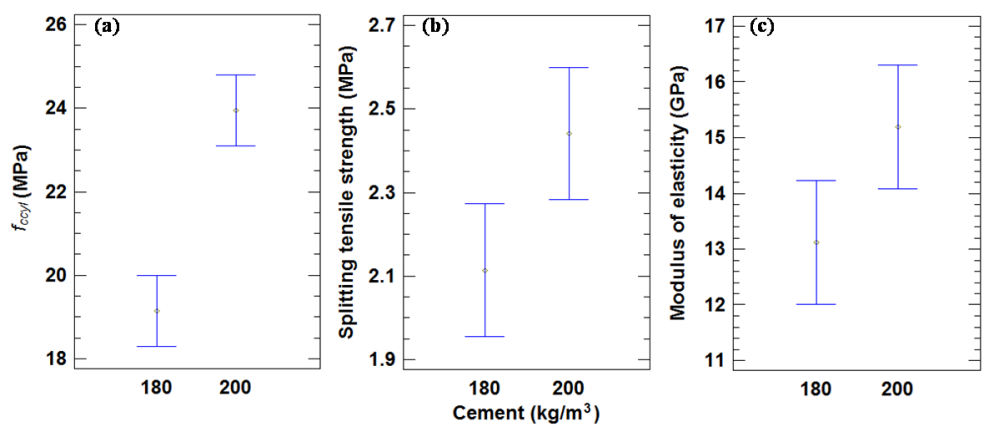

Figure 3. (a) Mean values of compressive strength in cylindrical specimens and 95\% LSD intervals vs. amount of cement. (b) Mean values of splitting tensile strength and 95\% LSD intervals vs. amount of cement. (c) Mean values of modulus of elasticity 95\% LSD intervals vs. amount of cement.

According to the ACI Code 318-08 [50], the mean compressive strength value $\left(f_{\mathrm{cm}}\right)$ at 28 days for concrete with a characteristic compressive strength $\left(f_{\mathrm{ck}}\right)$ under $21 \mathrm{MPa}$, when there are insufficient data to establish a standard deviation of the sample, is given by the following expression:

$$
f_{\mathrm{cm}}=f_{\mathrm{ck}}+7
$$


The values of $f_{\text {ck }}$ estimated by equation [1] for each concrete mixture are shown in Table 9 . Six of the mixes, corresponding to a cement content of $200 \mathrm{~kg} / \mathrm{m}^{3}$, had an $f_{\mathrm{ck}}$ greater than $15 \mathrm{MPa}$, which complies with the requirements of the Spanish standard EHE-08 for non-structural concrete. Only the concrete made with $100 \%$ MRA1 replacement had a slightly lower $f_{\mathrm{ck}}$ value (14 MPa). None of the other mixes $\left(180 \mathrm{~kg} / \mathrm{m}^{3}\right)$ complied with the EHE-08 requirement. This fact does not mean that they cannot be used in applications such as drainage ditches, sidewalks, trench filling and other non-structural uses, whose strength requirements are very low.

Table 9. The $f_{\text {ck }}$ values estimated by ACI Code 318-08.

\begin{tabular}{|c|c|c|c|c|c|c|c|}
\hline \multirow{2}{*}{$\begin{array}{c}\text { Cement content } \\
\text { Samples }\end{array}$} & \multicolumn{7}{|c|}{$180 \mathrm{~kg}$ of Cement $/ \mathrm{m}^{3}$} \\
\hline & $\mathrm{CC}$ & CMRA1-20 & CMRA1-40 & CMRA1-100 & CMRA2-20 & CMRA2-40 & CMRA2-100 \\
\hline$f_{\mathrm{cm}}$ & 21 & 20 & 19 & 17 & 20 & 19 & 19 \\
\hline$f_{\mathrm{ck}}$ & 14 & 13 & 12 & 10 & 13 & 12 & 12 \\
\hline Cement content & \multicolumn{7}{|c|}{$200 \mathrm{~kg}$ of Cement $/ \mathrm{m}^{3}$} \\
\hline $\begin{array}{c}\text { Samples } \\
f_{\mathrm{cm}} \\
f_{\mathrm{ck}}\end{array}$ & $\begin{array}{l}\text { CC } \\
26 \\
19\end{array}$ & $\begin{array}{c}\text { CMRA1-20 } \\
25 \\
18\end{array}$ & $\begin{array}{c}\text { CMRA1-40 } \\
24 \\
17\end{array}$ & $\begin{array}{c}\text { CMRA1-100 } \\
21 \\
14\end{array}$ & $\begin{array}{c}\text { CMRA2-20 } \\
25 \\
18\end{array}$ & $\begin{array}{c}\text { CMRA2-40 } \\
25 \\
18\end{array}$ & $\begin{array}{c}\text { CMRA2-100 } \\
23 \\
16\end{array}$ \\
\hline
\end{tabular}

The relationship between the compressive strengths of cylindrical and cubic specimens is plotted in Figure 4, with a good linear relationship $\left(R^{2}=0.92\right)$.

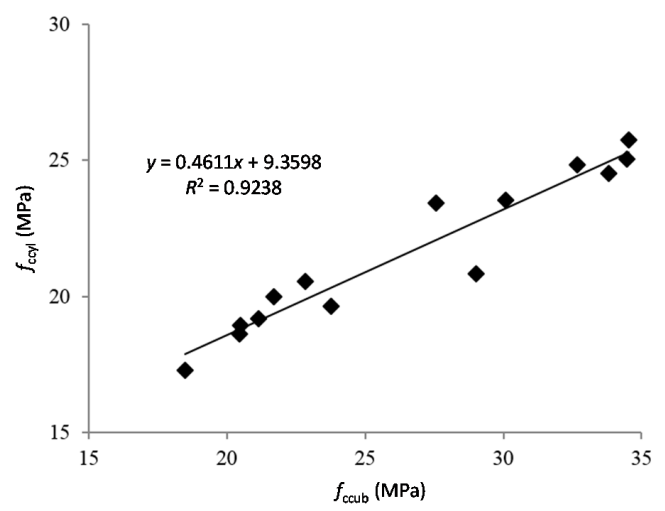

Figure 4. Correlation between compressive strength values for cylinder and cubic specimens at 28 days.

Table 7 indicates the mean splitting tensile strength values for each concrete mixture. The non-overlapping bars in Figure 3 show that there were statistically significant differences in the splitting tensile strength based on the amount of cement with a $95 \%$ confidence level. The mean values of the splitting tensile strength for all of the mixes with 200 and $180 \mathrm{~kg}$ of cement $/ \mathrm{m}^{3}$ were 2.44 and $2.12 \mathrm{MPa}$, respectively, with a decrease of $13.3 \%$ from the higher content to the lower one. Mas et al. [23] obtained a higher splitting tensile strength decrease (35.9\%). This agrees with the statement of Neville [51] who affirmed that the compressive and tensile strengths decline with the cement content, but the latter at a lower rate.

The mean values of the static modulus of elasticity are shown in Table 7. The mean values for all of the mixes with 200 and $180 \mathrm{~kg}$ of cement $/ \mathrm{m}^{3}$ were 15.2 and $13.1 \mathrm{GPa}$, respectively. The decrease in the modulus of elasticity between both mixes was $13.8 \%$, which is similar to the splitting tensile strength decrease $(13.3 \%)$. Figure 3 shows that there were no statistically significant differences between the two cement contents in modulus of elasticity property, as indicated by the overlapping bars.

\subsubsection{Physical Properties}

Four different physical properties of concrete, namely the saturated surface dry density (SSD density), water penetration under pressure, porosity, and water sorptivity were estimated. The results 
are shown in Table 7. The mean density values for all of the mixes with 200 and $180 \mathrm{~kg}$ of cement $/ \mathrm{m}^{3}$ were 2.31 and $2.26 \mathrm{Mg} / \mathrm{m}^{3}$, respectively. The decrease in the SSD density between the two series was $2.25 \%$. In contrast, Mas et al. [23] obtained a decrease of $1.28 \%$ between 360 and $240 \mathrm{~kg}$ of cement $/ \mathrm{m}^{3}$. The analysis shown in Figure 5 did not yield any statistically significant differences at a $95 \%$ confidence level, indicated by the lack of overlapping bars.
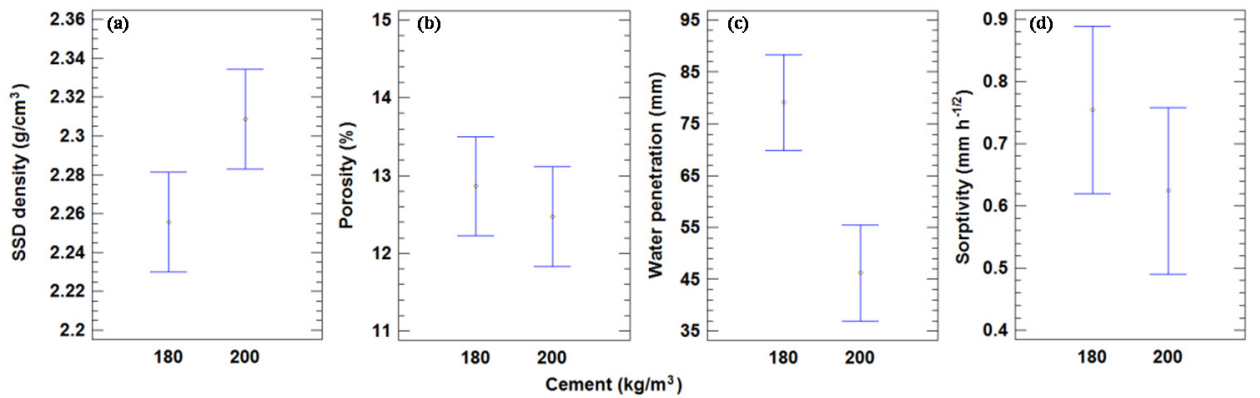

Figure 5. (a) Mean values of SSD density and 95\% LSD intervals vs. amount of cement. (b) Mean values of porosity and 95\% LSD intervals vs. amount of cement. (c) Mean values of water penetration and 95\% LSD intervals vs. amount of cement. (d) Mean values of sorptivity and 95\% LSD intervals vs. amount of cement.

The mean values of the porosity are given in Table 7. Figure 5 indicates that a higher cement content reduces the porosity and consequently increases the density. There were no significant differences in porosity with a 95\% confidence level. The mean values for all mixes with 200 and $180 \mathrm{~kg}$ of cement $/ \mathrm{m}^{3}$ were $12.5 \%$ and $12.9 \%$, respectively, with an increase of $3.2 \%$ between both series.

The mean values of water penetration under pressure for all concrete mixtures are given in Table 7 , and the value for the mixes with 200 and $180 \mathrm{~kg}$ of cement $/ \mathrm{m}^{3}$ were 52.6 and $79.1 \mathrm{~mm}$, respectively, (a difference of $50.4 \%$ ). This is consistent with the higher porosity and lower density of the second series. Figure 5 shows that there were significant differences between the series, as the amount of cement had a great effect on the water penetration under pressure. The results of Mas et al. [23] showed an increase of $114 \%$ between 360 and $240 \mathrm{~kg}$ of cement $/ \mathrm{m}^{3}$, which is greater than that seen in our results. This could be attributed to the lower cement content $(10 \%)$ in the present probes than in those used in their tests (33\%).

The mean values of sorptivity for all the mixes with 200 and $180 \mathrm{~kg}$ of cement $/ \mathrm{m}^{3}$ were 0.62 and $0.75 \mathrm{~mm} \cdot \mathrm{h}^{-1 / 2}$, respectively, with an increase of $20.2 \%$.

Strong linear relationships were found between the sorptivity, density, and porosity, as depicted in Figure 6. Sorptivity declines as the density increases and increases as the porosity increases.

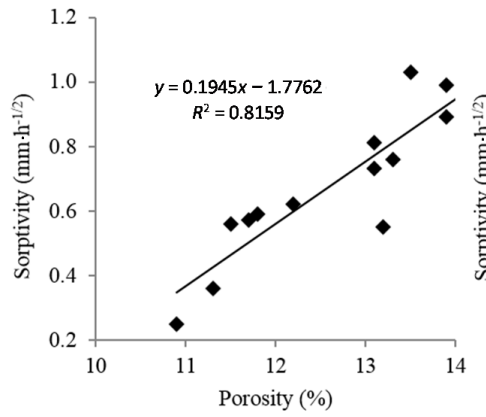

(a)

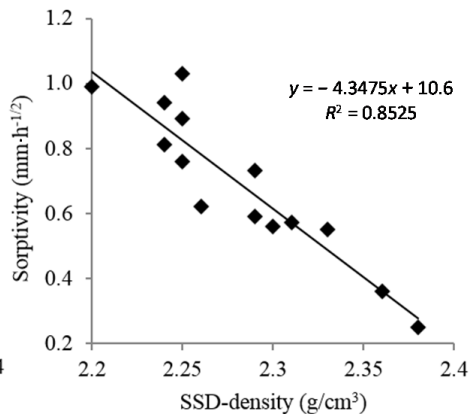

(b)

Figure 6. (a) Correlation between porosity with sorptivity. (b) Correlation between SSD density with sorptivity. 


\subsection{Effect of Replacement Ratio}

\subsubsection{Mechanical Properties}

The mean compressive strength of the concrete mixes with $20 \%$ of the coarse aggregate replaced was $4 \%$ less than the mean value of the control mixes after 28 days. The non-overlapping bars in Figure 7 indicate that there was no statistically significant difference between these series of mixes. Mas et al. [25] concluded that the reduction in the mean compressive strength after 28 days in concrete made with coarse MRA was $8.1 \%$ for a $20 \%$ replacement level and $250 \mathrm{~kg}$ of cement $/ \mathrm{m}^{3}$. This could be attributed to the fact that in a concrete manufactured with low cement content, the quality of coarse aggregate has a minor influence on strength.

The result was $7.8 \%$ less than the mean value of CCs with a $40 \%$ replacement ratio, and statistically significant differences in these two series of mixes did occur. These results contrast with those of Medina et al. [24], who found an $18.4 \%$ difference with $323 \mathrm{~kg}$ of cement $/ \mathrm{m}^{3}$ and $50 \%$ replacement ratio. Their result could be attributed to the larger amount of cement used.
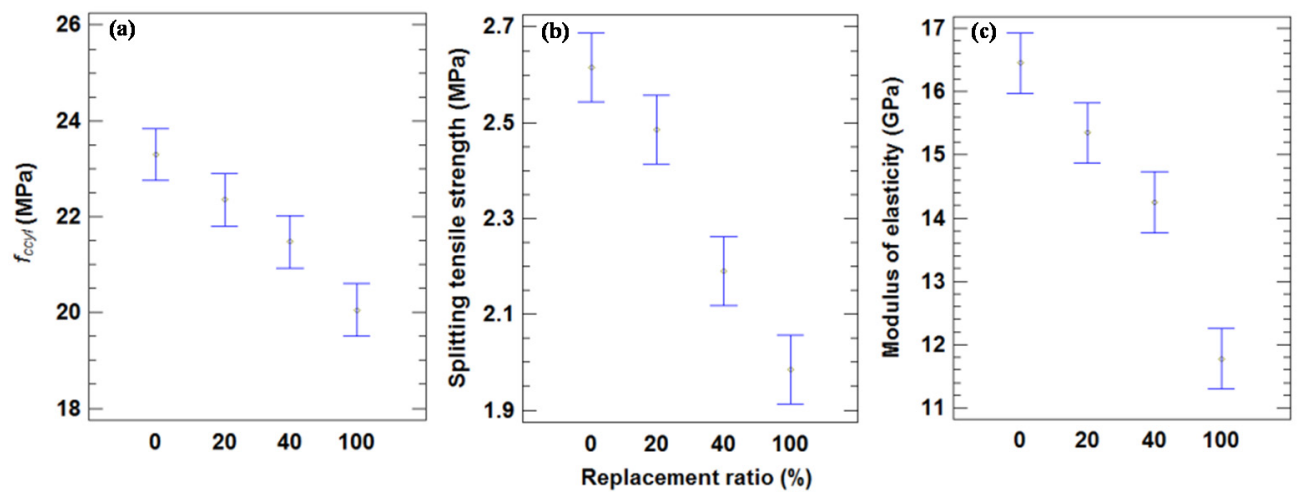

Figure 7. (a) Mean values of compressive strength in cylindrical specimens and 95\% LSD intervals vs. replacement ratio. (b) Mean values of splitting tensile strength compressive strength in cylindrical specimens and 95\% LSD intervals vs. replacement ratio. (c) Mean values of modulus of elasticity and 95\% LSD intervals $v s$. replacement ratio.

In the case of the total replacement of coarse aggregate, the decrease was $13.9 \%$, significantly different from the other mixes. Martinez-Lage et al. [26] estimated the loss for concrete with 100\% replacement was $23 \%$, with values ranging from $20 \%$ for $250 \mathrm{~kg}$ of cement $/ \mathrm{m}^{3}$ to $31 \%$ for $290 \mathrm{~kg}$ of cement $/ \mathrm{m}^{3}$. These results were similar to those obtained by Ihobe [21], who found a $25 \%$ decrease relative to the control concrete with $250 \mathrm{~kg}$ of cement $/ \mathrm{m}^{3}$; Brito et al. [17] reached a reduction of $43.48 \%$ for total replacement with $346.7 \mathrm{~kg}$ of cement $/ \mathrm{m}^{3}$. These results indicate that for a percentage of replacement, the loss of strength was smaller as the amount of cement decreased. This observation agrees with findings by Mas et al. [23], who found that concretes with MRA had lower percentages of reduction of unconfined compressive strength than concretes with a higher cement content.

Figure 8 represents the loss of mean values of the mechanical properties $\left(f_{\text {ccyl }}\right)$, splitting tensile strength and modulus of elasticity, with the replacement ratio. A strong linear relationship exists between the loss of mechanical properties relative to CCs and the replacement ratio.

No statistically significant differences in the splitting tensile strength ( $95 \%$ confidence level) between CCs and a 20\% replacement level were observed in the data of Figure 7 . The loss of strength was $5.0 \%$; this result agrees with findings by Mas et al. [23], who measured $6.8 \%$ for the same replacement level with $240 \mathrm{~kg} / \mathrm{m}^{3}$ of CEM II.

For $40 \%$ replacement, the decrease in splitting tensile strength relative to CCs was $16.2 \%$, which is a statistically significant difference from both a $20 \%$ replacement level mix and the CCs. These results 
contrast with those of Mas et al. [25], who concluded that the reduction in average tensile strength was $10 \%$ for a $40 \%$ replacement level with $240 \mathrm{~kg}$ of cement $/ \mathrm{m}^{3}$.

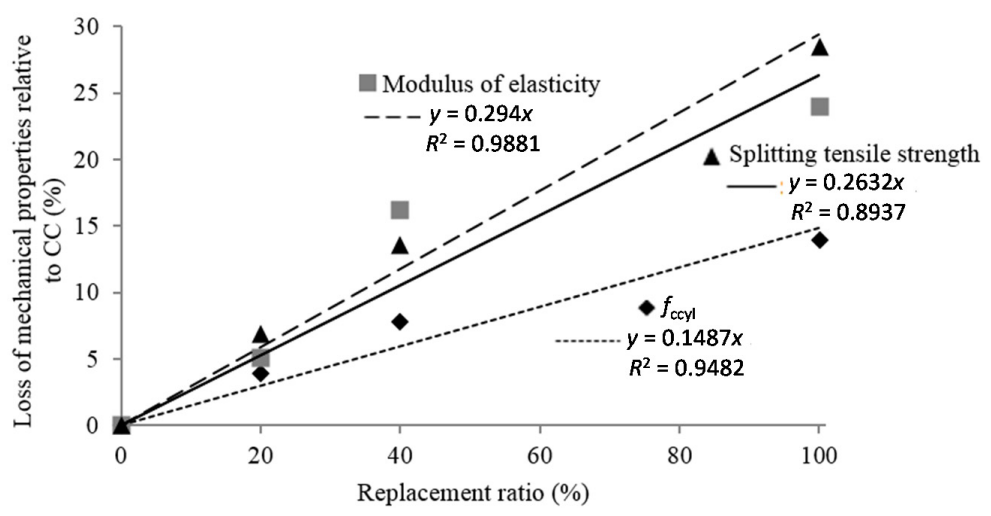

Figure 8. Loss of mean compressive strength, tensile strength, and modulus of elasticity relative to control concrete (CC) in relation to the replacement ratio.

A $24 \%$ decrease was measured with total replacement with respect to CC. Yang et al. [19] obtained a $30.5 \%$ loss for concrete with $100 \%$ mixed recycled aggregate for $435 \mathrm{~kg}$ of cement $/ \mathrm{m}^{3}$. This higher reduction is due to the larger cement content used in their study.

The modulus of elasticity varied in the same way as the compressive and splitting tensile strength. The mean value of the modulus of elasticity with a $20 \%$ replacement level was $15.34 \mathrm{GPa}$. This was $6.8 \%$ less than the mean value for CCs $(16.46 \mathrm{GPa})$. For a $40 \%$ replacement level, the mean value was 14.22 GPa, with a decrease of $13.6 \%$ relative to CCs. With full replacement, the decrease was $28.4 \%$. This result is in accordance with the results of Martinez-Lage et al. [26] and Ihobe [21], who estimated decreases of $34 \%$ and $28 \%$, respectively, for total replacement in concrete manufactured with MRA. Figure 7 shows that there were statistically significant differences between all replacement ratios.

\subsubsection{Physical Properties}

Figure 9 shows that there were significant differences between the SSD density of CCs and all replacement ratios. The SSD density decreased as the replacement levels of the MRA increased; this was due to the low density of MRA compared to NA. The mean SSD density for $20 \%, 40 \%$, and $100 \%$ replacement ratios, decreased by $1.8 \%, 2.9 \%$, and $4.4 \%$, respectively. Mas et al. [25] found a 3.3\% loss of density for a concrete with $240 \mathrm{~kg} / \mathrm{m}^{3}$ of CEM II and 20\% MRA replacement. Martinez-Lage et al. [26] found a $7.7 \%$ decline with a $100 \%$ MRA replacement and $250-290 \mathrm{~kg} / \mathrm{m}^{3}$ of CEM II. These higher values could be attributed to the larger cement content used.
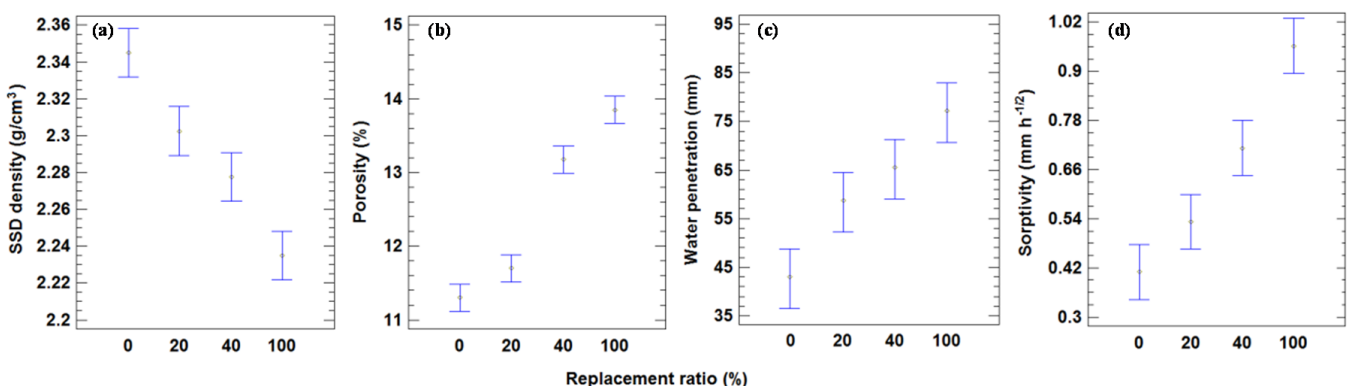

Figure 9. (a) Mean values of SSD density and 95\% LSD intervals vs. replacement ratio. (b) Mean values of porosity and 95\% LSD intervals $v$ s. replacement ratio. (c) Mean values of water penetration and 95\% LSD intervals vs. replacement ratio. (d) Mean values of sorptivity and 95\% LSD intervals vs. replacement ratio. 
As seen in Figure 9, there were significant differences in porosity between all replacement levels, showing that this factor had an important effect on porosity. The mean value of porosity for $20 \%$, $40 \%$, and $100 \%$ replacement levels increased relative to CCs by $3.4 \%, 16.3 \%$, and $22.4 \%$, respectively. Beltran et al. [52] found $1.75 \%$ and $6.3 \%$ growth for a concrete manufactured with $300 \mathrm{~kg}$ of cement $/ \mathrm{m}^{3}$ and with a $20 \%$ and $100 \%$ replacement of coarse NA by RCA, respectively. This minor growth could be attributed to the greater density of RCA compared to MRA.

Figure 10 indicates that a strong linear correlation exists between the decrease in SSD density $\left(R^{2}=0.86\right)$ and replacement ratio, and the increase in porosity $\left(R^{2}=0.85\right)$ and replacement ratio.

Figure 9 shows that there were no significant differences between CCs and a $20 \%$ replacement mix in water penetration under pressure. A $28.4 \%$ increment of maximum water penetration under pressure was found with a $20 \%$ replacement level relative to the control. Total replacement resulted in an $80.4 \%$ increment of maximum water penetration under pressure relative to CCs.

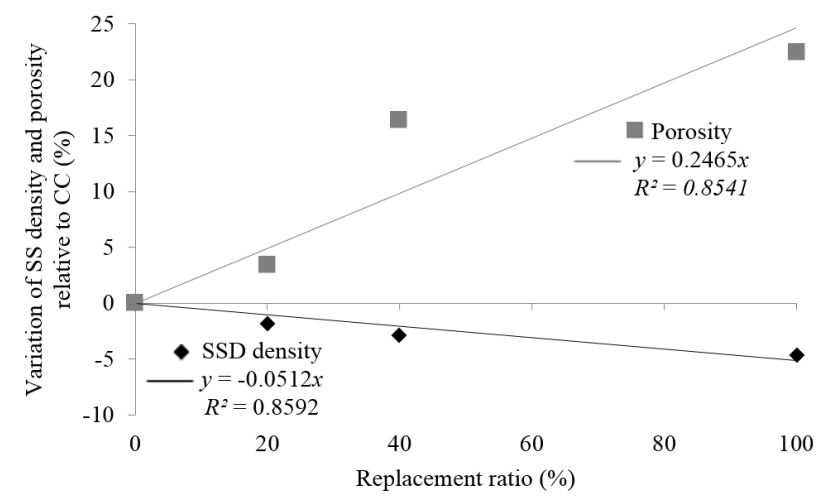

Figure 10. Loss of mean of SSD density and porosity variation relative to CC in relation to the replacement ratio.

Figure 11 indicates that the maximum water penetration under pressure and sorptivity increases linearly with the replacement ratio, with a high correlation index, 0.90 and 0.97 , respectively. The maximum water penetration under pressure for the series with $200 \mathrm{~kg}$ of cement $/ \mathrm{m}^{3}$ varied between $34 \mathrm{~mm}$ for CCs and $78 \mathrm{~mm}$ for $100 \%$ replacement with MRA1. These results agree with those obtained by Mas et al. [25] and Correia et al. [53].

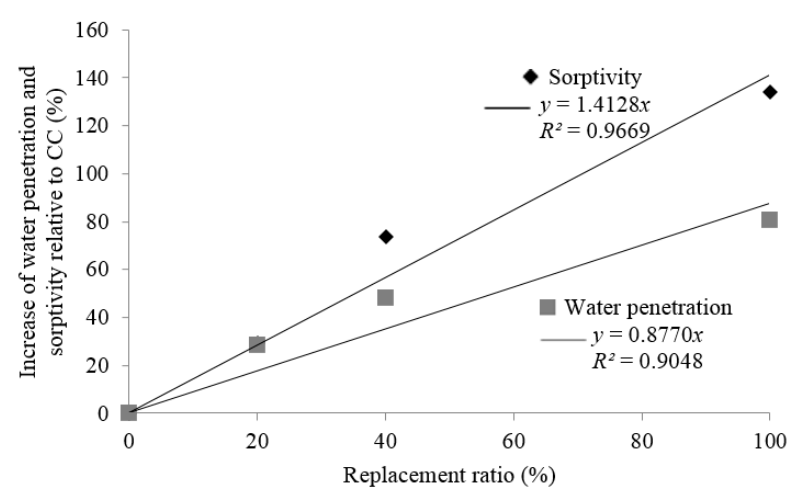

Figure 11. Loss of mean of water penetration and sorptivity increase relative to CC in relation to the replacement ratio.

Figure 9 does not show significant differences (95\% confidence level) between CCs and 20\% replacement in the sorptivity property. A $20 \%$ replacement ratio relative to CCs produced a $29.2 \%$ increase in sorptivity; this may be due to the higher porosity of concrete with $20 \%$ replacement. 
For $40 \%$ replacement, the increase in sorptivity relative to CCs was $73.4 \%$, similar to Etxeberría et al. [27] (65.2\%) for similar probes (23\% ceramic content of MRA and $240 \mathrm{~kg}$ of CEM II $/ \mathrm{A}-\mathrm{V} / \mathrm{m}^{3}$ ). Medina et al. [24] found an increase of $13 \%$ for $50 \%$ substitution; this lower value could be attributed to the larger cement content used $\left(323 \mathrm{~kg}\right.$ of CEM I $\left./ \mathrm{m}^{3}\right)$, resulting in a higher density, as well as the lower ceramic material content (5.3\%) in relation to that used in this study (13.9\% for MRA1 and $30.2 \%$ for MRA2). For total replacement, the gain in sorptivity was $134.1 \%$ relative to CCs, which is very similar to the results obtained by Sanchez [22], who found a $133 \%$ increase with $240-265 \mathrm{~kg}$ of cement $/ \mathrm{m}^{3}$. Conversely, Correia et al. [53] found an increase of $70.4 \%$, but with a cement content of $346.7 \mathrm{~kg} / \mathrm{m}^{3}$.

\subsection{Effect of Type of Aggregate}

\subsubsection{Mechanical Properties}

There were no statistically significant differences between the mechanical properties analyzed and the type of aggregate, as shown by the overlapping bars in Figure 12. This statistical result only confirms that the RA used in this work had similar characteristics. As a comparison between the two types of aggregates, the MRA1 mean compressive strength at 28 days was $20.74 \mathrm{MPa}$, and the same value for MRA2 was $21.85 \mathrm{MPa}$. This may be because the Los Angeles value of MRA1 is higher than that of MRA2, as observed by Ramesh Kumar and Sharma [54].

Although there is no significant difference in the magnitude of the compressive strength between each type of aggregate, the results suggest a clear trend that does differ by the two types studied (Figure 13). The reduction of the compressive strength between the CMRA1-100-I/II and CC-I/II (9\% for both series I and II) is greater than that of CMRA2-100-I/II (17.1\% for series I and $20.2 \%$ for series II). MRA2 is apparently less harmful to concrete mixtures than MRA1.
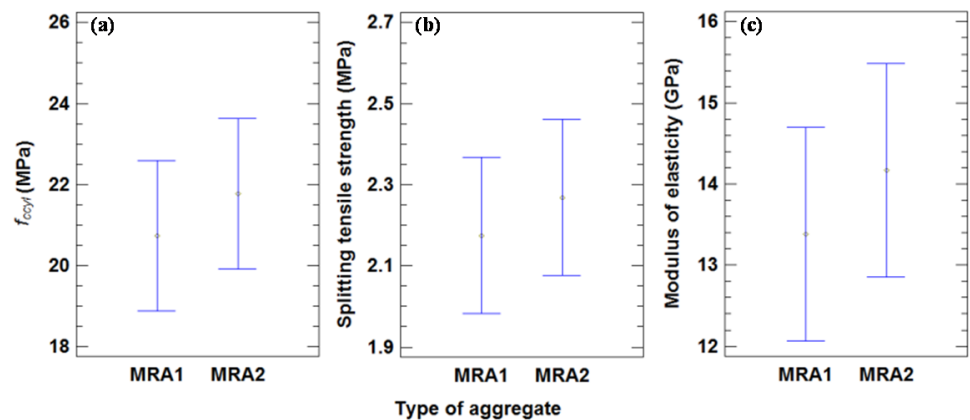

Figure 12. (a) Mean values of compressive strength in cylindrical specimens and 95\% LSD intervals vs. type of MRA. (b) Mean values of splitting tensile strength compressive strength in cylindrical specimens and 95\% LSD intervals vs. type of MRA. (c) Mean values of modulus of elasticity and 95\% LSD intervals vs. type of MRA.

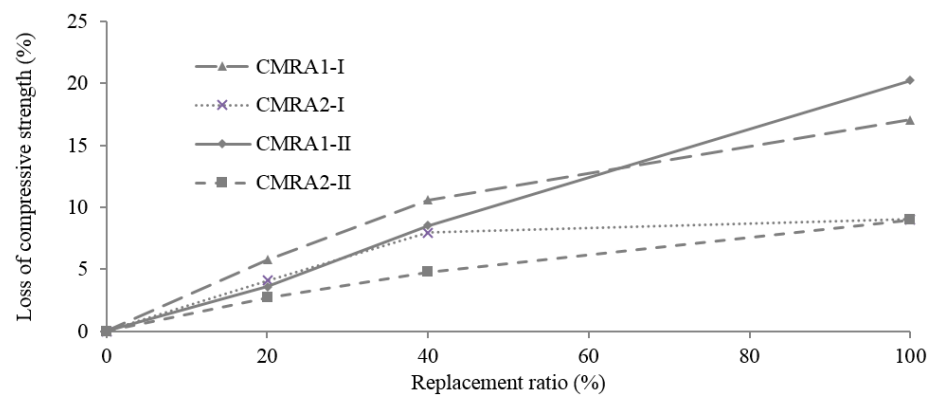

Figure 13. Loss of compressive strength, $f_{\text {ccyl }}$, relative to CC with the replacement ratio. 
The mean splitting tensile strength after 28 days for each type of aggregate was very similar: 2.17 and 2.27 MPa for MRA1 and MRA2, respectively. The higher strength of MRA2 may be due to the minor Los Angeles coefficient of this aggregate, which occurs for the compressive strength. The difference in splitting tensile strength was $4.3 \%$, which is similar to the difference in compressive strength $(5.0 \%)$.

The mean value of the modulus of elasticity for the concrete mixtures with MRA1 was $13.38 \mathrm{GPa}$, which was 5.6\% lower than the mean value with MRA2 (14.17 GPa). These results were similar to the compressive strength decrease (5.0\%). However, there was no significant difference between the modulus of elasticity and two types of aggregates, although the results show a greater reduction in the modulus of elasticity for CMRA1-100-I/II in relation to CC-I/II (31.5\% for I and 33.9\% for II) than CMRA2-100-I/II to CC-I/II (22.3\% for I and 25.7\% for II) due to the minor Los Angeles coefficient of this aggregate.

\subsubsection{Physical Properties}

There were no significant differences between the physical properties analyzed and the type of aggregate, as seen in Figure 14. The mean SS densities for MRA1 and MRA2 were 2.29 and $2.26 \mathrm{Mg} / \mathrm{m}^{3}$, respectively. The low density of concretes with MRA2 was due to the low density of this aggregate, as seen in Table 1.
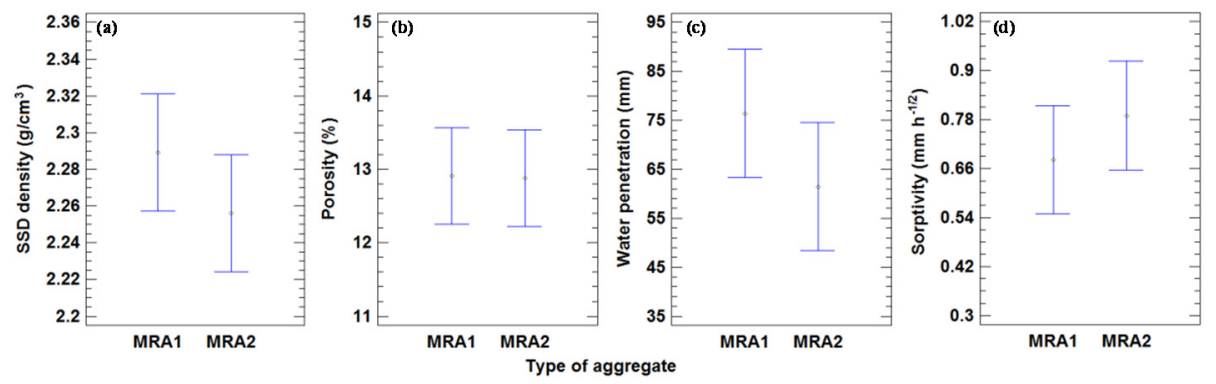

Figure 14. (a) Mean values of SSD density and 95\% LSD intervals vs. type of MRA. (b) Mean values of porosity and 95\% LSD intervals vs. type of MRA. (c) Mean values of water penetration and 95\% LSD intervals vs. type of MRA. (d) Mean values of sorptivity and 95\% LSD intervals vs. type of MRA.

The mean values of maximum water penetration for MRA1 and MRA2 were 76.4 and $62.1 \mathrm{~mm}$, respectively, with a decline of $18.7 \%$. These great penetration values exert an appreciable influence on the durability of concrete. Nevertheless, this result is not restrictive for the main purpose of this work, which is to manufacture a non-structural concrete to use without steel bars for reinforcement.

Mean sorptivity for MRA1 and MRA2 was 0.68 and $0.79 \mathrm{~mm} \cdot \mathrm{h}^{-1 / 2}$, respectively. These results agreed with those of Etxeberría et al. [27], who obtained mean sorptivity values of $0.515 \mathrm{~mm} \cdot \mathrm{h}^{-1 / 2}$ for MRA with cement content of between 240 and $265 \mathrm{~kg} / \mathrm{m}^{3}$.

\section{Conclusions}

The mechanical and physical properties of concrete made with MRA and low cement content were analyzed in manufacturing a non-structural, low-strength concrete (15 MPa) using the highest substitution percentage of MRA in the coarse fraction. Based on the results obtained in this study, the following conclusions can be drawn:

- The main factors that affect the properties analyzed in this research are the amount of cement and the replacement ratio.

- The type of aggregate used in this research had no statistically significant effects on the properties analyzed. 
- Excellent linear correlations between the percentage of substitution and loss of compressive strength, tensile strength, and the modulus of elasticity were found. These losses decrease with the amount of cement.

- Excellent linear correlations between the replacement ratio and increases in porosity, depth of water penetration under pressure and sorptivity were found. These are properties that adversely affect the durability, but the correlations do not present a negative impact for the purpose of this study, as a concrete without steel reinforcement is being sought.

- A replacement ratio of up to $20 \%$ of coarse natural aggregates by MRA presents no statistically significant differences in strength properties compared with the control concrete.

- It is possible to achieve a non-structural, low-strength concrete (15 MPa) with an MRA replacement ratio of up to $100 \%$ with $200 \mathrm{~kg} / \mathrm{m}^{3}$ of cement. Previous studies have used cement quantities exceeding $240 \mathrm{~kg} / \mathrm{m}^{3}$ for manufacturing non-structural concretes with MRA.

- Even though non-structural concrete made with MRA is not allowed by Spanish Code EHE-08, the results obtained here support its viability. Experimentation on a larger scale is required to confirm these results. This concrete could be used in the construction of ditches, sidewalks, and similar works, with the environmental benefits indicated above.

Acknowledgments: The authors would like to thank the European Regional Development's Fund (ERDF) of the European Union for financial support via the project "Applications of recycled aggregates from construction and demolition waste (CDW) for the sustainable development of road infrastructure in central areas of Andalusia" from the "2007-2013 ERDF Operational Programme for Andalusia". We also thank the Public Works Agency and Regional Ministry of Public Works and Housing of the Regional Government of Andalusia staff and researchers for their dedication and professionalism, and PREBESUR SL, for his support in the concrete mix proportion design. Cements used in this research were freely provided by Votorantim Group.

Author Contributions: Jesús Ayuso and María José Sierra conceived and designed the experiments; Antonio López-Uceda performed the experiments; Martin López, Francisco Agrela and Antonio López-Uceda analyzed the data; Antonio López-Uceda, Jesús Ayuso and José Ramón Jimenez also wrote the paper.

Conflicts of Interest: The authors declare no conflict of interest.

\section{References}

1. Higuchi, T.; Moriokaa, M.; Yoshioka, I.; Yokozeki, K. Development of a new ecological concrete with $\mathrm{CO}_{2}$ emissions below zero. Constr. Build. Mater. 2014, 67, 338-343. [CrossRef]

2. De Schepper, M.; van den Heede, P.; van Driessche, I.; de Belie, N. Life cycle assessment of completely recyclable concrete. Materials 2014, 7, 6010-6027. [CrossRef]

3. Damtoft, J.S.; Lukasik, J.; Herfort, D.; Sorrentino, D.; Gartner, E.M. Sustainable development and climate change initiatives. Cem. Concr. Res. 2008, 38, 115-127. [CrossRef]

4. European Commision (DG ENV). Final Report Task 2: Service Contract on Management of Construction and Demolition Waste Prepared by Bio Intelligent Service. 2011. Available online: http:/ / ec.europa.eu/ environment/waste/pdf/2011_CDW_Report.pdf (accessed on 3 April 2015).

5. European Environment Agency. EU as a Recycling Society-Present Recycling Levels of Municipal Waste and Construction \& Demolition Waste in the EU. 2009. Available online: http://scp.eionet.europa.eu/ publications/wp2009_2/wp/WP2009_2 (accessed on 7 April 2015).

6. Van der Sloot, H.A. Readily accessible data and integrated approach is needed for evaluating waste treatment options and preparation of materials for beneficial use. Waste Manag. 2009, 24, 751-752. [CrossRef] [PubMed]

7. Eikelboom, R. Challenges environmental evaluation and use of recycling materials. In Proceedings of the 6th International Conference Environmental and Technical Implications of Construction with Alternative Materials, Belgrade, Serbia, 30 May-2 June 2006.

8. Knoeri, C.; Sanye-Mengual, E.; Althau, H.J. Comparative LCA of recycled and conventional concrete for structural applications. Int. J. Life Cycle Assess. 2013, 18, 909-918. [CrossRef]

9. Boletín Oficial del Estado (BOE). Plan Nacional Integrado de Residuos para el período 2008-2015. 2009. Available online: https://www.boe.es/boe/dias/2009/02/26/pdfs/BOE-A-2009-3243.pdf (accesed on 7 April 2015). (In Spanish). 
10. CEDEX. Catálogo de Residuos. Residuos de Construcción y Demolición 2010. Available online: http://www. cedexmateriales.vsf.es/view / catalogo.aspx (accessed on 7 April 2015). (In Spanish).

11. Spanish Ministry of Public Works. Code on Structural Concrete, EHE-08, Permanent Commission of the Concrete; Spanish Ministry of Public Works: Madrid, Spain, 2008.

12. Gonçalves, P.; de Brito, J. Recycled aggregate concrete (RAC) comparative analysis of existing specifications. Mag. Concr. Res. 2010, 62, 339-346. [CrossRef]

13. Thomas, C.; Setién, J.; Polanco, J.A.; Alaejos, P.; Sanchez de Juan, M. Durability of recycled aggregate concrete. Constr. Build. Mater. 2013, 40, 1054-1065. [CrossRef]

14. Rahal, K. Mechanical properties of concrete with recycled coarse aggregate. Build. Environ. 2007, 42, 407-415. [CrossRef]

15. Exteberria, M.; Vázquez, E.; Marí, A.; Barra, M. Influence of amount of recycled coarse aggregates and production process on properties of recycled aggregate concrete. Cem. Concr. Res. 2007, 37, 735-742.

16. Malešev, M.; Radonjanin, V.; Marinković, S. Recycled concrete as aggregate for structural concrete production. Sustainability 2010, 2, 1204-1225. [CrossRef]

17. Brito, J.; Pereira, A.S.; Correia, J.R. Mechanical behaviour of non-structural concrete made with recycled ceramic aggregates. Cem. Concr. Compos. 2005, 27, 429-433. [CrossRef]

18. Cachim, P.B. Mechanical properties of brick aggregate concrete. Constr. Build. Mater. 2009, 23, $1292-1297$. [CrossRef]

19. Yang, J.; Du, Q.; Bao, Y. Concrete with recycled concrete aggregate and crushed clay bricks. Constr. Build. Mater. 2011, 25, 1935-1945. [CrossRef]

20. Guerra, I.; Vivar, I.; Llamas, B.; Juan, A.; Moran, J. Eco-efficient concretes: The effects of using recycled ceramic material from sanitary installations on the mechanical properties of concrete. Constr. Build. Mater. 2009, 29, 643-646. [CrossRef] [PubMed]

21. Ihobe. Usos de áridos reciclados mixtos procedentes de Residuos de Construcción y Demolición. Available online: http://www.caminospaisvasco.com/Profesion/documentostecnicos/usosaridos (accessed on 7 April 2015). (In Spanish).

22. Sanchez, R. Análisis de la Aplicabilidad de los Áridos Reciclados Mixtos en Hormigones. Tesina de Especialidad, Universidad Politécnica de Cataluña, Barcelona, España, 2011. (In Spanish).

23. Mas, B.; Cladera, A.; del Olmo, T.; Pitarch, F. Influence of the amount of mixed recycled aggregates on the properties of concrete for non-structural use. Constr. Build. Mater. 2012, 27, 612-622. [CrossRef]

24. Medina, C.; Zhu, W.; Howind, T.; Sánchez de Rojas, M.I.; Frías, M. Influence of mixed recycled aggregate on the physical-mechanical properties of recycled concrete. J. Clean. Prod. 2014, 68, 216-225. [CrossRef]

25. Mas, B.; Cladera, A.; Bestard, J.; Muntaner, D.; López, C.E.; Piña, S.; Prades, J. Concrete with mixed recycled aggregates: Influence of the type of cement. Constr. Build. Mater. 2012, 34, 430-441. [CrossRef]

26. Martínez-Lage, I.; Martínez-Abella, F.; Vázquez-Herrero, C.; Luis Pérez-Ordóñez, J.L. Properties of plain concrete made with mixed recycled coarse aggregate. Constr. Build. Mater. 2012, 37, 171-176. [CrossRef]

27. Etxeberria, M.; Gonzalez Corominas, A.; Valero López, I. Application of low grade recycled aggregates for non-structural concrete production in the city of Barcelona. In Proceedings of the Third International Conference on Sustainable Construction Materials and Technologie, Kyoto, Japan, 18-21 August 2013.

28. The International Union of Laboratories and Experts in Construction Materials, Systems and Structures (RILEM) Recommendation. Specifications for concrete with recycled aggregates. Mater. Struct. 1994, 27, 557-559.

29. Agrela, F.; de Juan, M.S.; Ayuso, J.; Geraldes, V.L.; Jiménez, J.R. Limiting properties in the characterisation of mixed recycled aggregates for use in the manufacture of concrete. Constr. Build. Mater. 2011, 25, 3950-3955. [CrossRef]

30. Silva, R.V.; de Brito, J.; Dhir, R.K. Properties and composition of recycled aggregates from construction and demolition waste suitable for concrete production. Constr. Build. Mater. 2014, 65, 201-217. [CrossRef]

31. Asociación Española de Normalización y Certificación. Tests for Mechanical and Physical Properties of Aggregates-Part. 6: Determination of Particle Density and Water Absorption; UNE-EN 1097-6:2014; Asociación Española de Normalización y Certificación (AENOR): Madrid, Spain, 2014.

32. Asociación Española de Normalización y Certificación. Tests for Geometrical Properties of Aggregates-Part. 3: Determination of Particle Shape-Flakiness Index; UNE-EN 933-3:2012; Asociación Española de Normalización y Certificación (AENOR): Madrid, Spain, 2012. 
33. Asociación Española de Normalización y Certificación. Tests for Mechanical and Physical Properties of Aggregates-Part. 2: Methods for the Determination of Resistance to Fragmentation; UNE-EN 1097-2:2010; Asociación Española de Normalización y Certificación (AENOR): Madrid, Spain, 2010.

34. Asociación Española de Normalización y Certificación. Tests for Thermal and Weathering Properties of Aggregates-Part. 2: Magnesium Sulfate Test; UNE-EN 1367-2:2010; Asociación Española de Normalización y Certificación (AENOR): Madrid, Spain, 2010.

35. Asociación Española de Normalización y Certificación. Tests for Chemical Properties of Aggregates-Part. 1: Chemical Analysis. Section 11. Determination of Water Soluble Total Sulfur; UNE-EN 1744-1-11:2010; Asociación Española de Normalización y Certificación (AENOR): Madrid, Spain, 2010.

36. Asociación Española de Normalización y Certificación. Tests for Chemical Properties of Aggregates-Part. 1: Chemical Analysis. Section 12. Determination of Acid-Soluble Sulphates; UNE-EN 1744-1-12:2010; Asociación Española de Normalización y Certificación (AENOR): Madrid, Spain, 2010.

37. Asociación Española de Normalización y Certificación. Tests for Chemical Properties of Aggregates-Part. 1: Chemical Analysis. Section 7. Determination of Total Water Soluble Chlorides; UNE-EN 1744-1-7:2010 Asociación; Española de Normalización y Certificación (AENOR): Madrid, Spain, 2010.

38. Asociación Española de Normalización y Certificación. Tests for Geometrical Properties of Aggregates-Part. 11: Classification Test for the Constituents of Coarse Recycled Aggregate; UNE-EN 933-11:2009; Asociación Española de Normalización y Certificación (AENOR): Madrid, Spain, 2009.

39. Española de Normalización y Certificación. Aggregates for Concrete Determination of the Coefficient of Friability of the Sands; UNE 83115:1989; Asociación Española de Normalización y Certificación (AENOR): Madrid, Spain, 1989.

40. Van den Heede, P.; de Belie, N. Environmental impact and life cycle assessment (LCA) of traditional and "green" concretes: Literature review and theoretical calculations. Cem. Concr. Compos. 2012, 34, 431-442. [CrossRef]

41. Española de Normalización y Certificación. Concrete-Part. 1: Specification, Performance, Production and Conformity; UNE-EN-206-1:2008; Asociación Española de Normalización y Certificación (AENOR): Madrid, Spain, 2008.

42. García-González, J.; Rodríguez-Robles, D.; Juan-Valdés, A.; Morán-del Pozo, J.M.; Guerra-Romero, M.I. Pre-saturation technique of the recycled aggregates: Solution to the water absorption drawback in the recycled concrete manufacture. Materials 2014, 7, 6224-6236. [CrossRef]

43. Asociación Española de Normalización y Certificación. Testing Fresh Concrete-Part. 2: Slump Test; UNE-EN 12350-2:2009; Asociación Española de Normalización y Certificación (AENOR): Madrid, Spain, 2009.

44. Asociación Española de Normalización y Certificación. Testing Hardened Concrete-Part. 3: Compressive Strength of Test Specimens; UNE-EN 12390-3:2009; Asociación Española de Normalización y Certificación (AENOR): Madrid, Spain, 2009.

45. Asociación Española de Normalización y Certificación. Testing Hardened Concrete-Part. 6: Tensile Splitting Strength of Test Specimens; UNE-EN 12390-6:2009; Asociación Española de Normalización y Certificación (AENOR): Madrid, Spain, 2009.

46. Asociación Española de Normalización y Certificación. Concrete Tests. Determination of the Modulus of Elasticity in Compression; UNE 83316:1996; Asociación Española de Normalización y Certificación (AENOR): Madrid, Spain, 1996.

47. Asociación Española de Normalización y Certificación. Testing Hardened Concrete - Part. 7: Density of Hardened Concrete; UNE-EN 12390-7:2009; Asociación Española de Normalización y Certificación (AENOR): Madrid, Spain, 2009.

48. Asociación Española de Normalización y Certificación. Testing Hardened Concrete-Part. 8: Depth of Penetration of Water under Pressure; UNE-EN 12390-8:2009; Asociación Española de Normalización y Certificación (AENOR): Madrid, Spain, 2009.

49. Asociación Española de Normalización y Certificación. Natural Stone Test Methods. Determination of Water Absorption Coefficient by Capillarity; UNE-EN 1925:1999; Asociación Española de Normalización y Certificación (AENOR): Madrid, Spain, 1999.

50. American Concrete Institute. Building Code Requirements for Structural Concrete; ACI 318-08; American Concrete Institute: Farmington Hills, MI, USA, 2008.

51. Neville, A.M. Properties of Concrete, 5th ed.; Pearson Education Limited: Essex, UK, 2012. 
52. Beltrán, M.G.; Barbudo, A.; Agrela, F.; Galvín, A.P.; Jiménez, J.R. Effect of cement addition on the properties of recycled concretes to reach control concretes strengths. J. Clean. Prod. 2014, 79, 124-133. [CrossRef]

53. Correia, J.R.; de Brito, J.; Pereira, A.S. Effects on concrete durability of using recycled ceramic aggregates. Mater. Struct. 2006, 39, 169-177. [CrossRef]

54. Ramesh Kumar, G.B.; Sharma, U.K. Abrasion resistance of concrete containing marginal aggregates. Constr. Build. Mater. 2014, 66, 712-722. [CrossRef]

(C) 2016 by the authors; licensee MDPI, Basel, Switzerland. This article is an open access article distributed under the terms and conditions of the Creative Commons by Attribution (CC-BY) license (http://creativecommons.org/licenses/by/4.0/). 